Yulia Anggraini Puspitaningtyas, Saino

\title{
Pengaruh Kualitas Produk, Electronic Word of Mouth (E-WOM), dan Lokasi terhadap Keputusan Pembelian Ayam Panggang Bu Setu di Gandu Magetan
}

\author{
Yulia Anggraini Puspitaningtyas \\ Universitas Negeri Surabaya \\ Saino \\ Universitas Negeri Surabaya \\ yuliapuspitaningtyas16080324076@mhs.unesa.ac.id \\ saino@unesa.ac.id
}

\begin{abstract}
Abstrak
Penelitian bertujuan untuk mengetahui pengaruh kualitas produk, electronic word of mouth, dan lokasi terhadap keputusan pembelian Ayam Panggang Bu Setu di Gandu Magetan. Jenis penelitian adalah penelitian survey dengan pendekatan kuantitatif. Populasi adalah konsumen yang telah melakukan pembelian Ayam Panggang $\mathrm{Bu}$ Setu dengan sampel berjumlah 153 responden. Pengambilan sampel memakai metode nonprobability sampling dengan teknik accidental sampling. Teknik analisis data dengan regresi linier berganda. Hasil penelitian menunjukkan bahwa kualitas produk $\left(\mathrm{X}_{1}\right)$ berpengaruh secara signifikan terhadap keputusan pembelian, dengaan nilai koefisien 0,113 , electronic word of mouth $\left(\mathrm{X}_{2}\right)$ secara signifikan berpengaruh terhadap keputusan pembelian dengaan nilai koefisien 0,128 , dan lokasi $\left(\mathrm{X}_{3}\right)$ secara signifikan berpengaruh terhadap keputusan pembelian dengaan nilai koefisien 0,284 . Secara simultan kualitas produk $\left(\mathrm{X}_{1}\right)$, electronic word of mouth $\left(\mathrm{X}_{2}\right)$, serta lokasi $\left(\mathrm{X}_{3}\right)$ berpengaruh siqnifikan terhadap keputusan pembelian dengan nilai Adjusted $R$ Square sebesar 0,236.
\end{abstract}

Kata Kunci: kualitas produk, electronic word of mouth, lokasi, dan keputusan pembelian.

\section{Pendahuluan}

Bisnis makanan di Kabupaten Magetan mengalami perkembangan yang pesat. Hal ini bisa dilihat banyaknya orang yang membuka bisnis makanan berawal dari skala kecil (warung di pinggir jalan), menengah (rumah makan, depot, dan café), dan besar (restoran di hotel berbintang). Saat ini usaha makanan persaingannya sangat ketat karena makanan sebagai kebutuhan utama masyarakat yang dapat ditemukan di mana saja. Adanya persaingan yang ketat di bisnis makanan, menyebabkan perusahaan menerapkan konsep pemasaran dengan mengetahui perilaku konsumen maupun keinginan konsumen agar mampu bersaing dengan perusahaan sejenis dan mengetahui berbagai faktor terjadinya keputusan bertransaksi.

Seseorang melakukan pembelian bisa terpengaruh oleh beberapa factor dan strategi yang dilakukan perusahaan dalam menarik konsumen. Ada beberapa faktor yang bisa mempengaruhi, yakni produk (product), harga (price), distribusi (distribution), promosi (promotion), layanan, dan masih banyak faktor lain..

Hasil penelitiannya dari Ellisshanty (2017), menyimpulkan bahwa harga berpengaruh negatif terhadap keputusan pembelian, tetapi kualitas produk dan promosi pengaruhnya positif terhadap keputusan bertransaksi. Penelitian Utami dkk (2016), menyatakan secara parsial electronic word of mouth pengaruhnya signifikan terhadap keputusan pembelian. Penelitian lain yang dilakukan Lili dan Afriani (2017), menjelaskan bahwa harga, kemasan 
produk, serta lokasi secara bersamaan berpengaruh secara signifikan terhadap keputusan membeli.

Dari hasil penelitian terdahulu dan relevansinya terhadap obyek penelitian, maka penelitian selanjutnya menggunakan sebagian variabel bauran pemasaran untuk penelitian di rumah makan Ayam Panggang Bu Setu di Gandu Kabupaten Magetan. Variabel tersebut meliputi kualitas produk, electronic word of mouth, serta lokasi usaha.

Di Kabupaten Magetan terutama di Desa Gandu banyak ditemui penjual ayam panggang. Salah satu usaha ayam panggang yang banyak digemari dan dicari konsumen yaitu ayam panggang milik $\mathrm{Bu}$ Setu. Kualitas produk merupakan salah satu unsur yang dipertimbangkan konsumen untuk menentukan pengambilan keputusan membeli di rumah makan Ayam tersebut. Kualitas produk Ayam Panggang Bu Setu sesuai dengan pendapat dari para konsumennya yang sudah melaksanakan keputusan membeli di rumah makan tersebut, di mana banyak konsumen yang menyatakan bahwa produknya memiliki keunggulan tersendiri yaitu daging ayam kampung dengan tekstur yang empuk merata dengan rasa yang pas. Kemudian, konsumen juga mengatakan bahwa bumbu yang dioleskan pada ayam panggang milik $\mathrm{Bu}$ Setu meresap sampai ke dalam daging sehingga banyak digemari dan dicari oleh para konsumen dibandingkan dengan rumah makan lain yang sejenis. Hal yang diperhatikan konsumen ialah kualitas produk sebelum membeli. Kualitas produk selalu diusahakan dan dijaga untuk memenuhi kebutuhan serta keinginan konsumen.

Bersamaan dengan cepatnya perkembangan teknologi informasi dan komunikasi, penyebaran informasi terkait keunggulan Ayam Panggang Bu Setu semakin viral melalui electronic word of mouth sehingga penjualan semakin meningkat. Tanpa disadari banyak konsumen yang telah memberikan informasi dan mempromosikan produk ayam panggang tersebur lewat media sosial, seperti instagram, facebook, youtube, dan sebagainya dalam bentuk video maupun tertulis secara online yang dapat memberikan publikasi akan produk tersebut. Konsumen yang merasa puas dengan pembelian Ayam Panggang akan merekomendasikan ke konsumen lain sehingga rumah makan Bu Setu mempunyai reputasi yang baik didalam forum chat atau media sosial. Dengan demikian, nama Ayam Panggang Bu Setu semakin dikenal lebih luas serta semakin banyak konsumen yang ingin menikmati hidangan di rumah makan tersebut.

Faktor lokasi sebagai pertimbangan konsumen saat melakukan keputusan pembelian, karena konsumen cenderung suka akan lokasi yang dekat dengan keramaian maupun pusat kota dan gampang terjangkau. Untuk bisa sampai ke lokasi Ayam Panggang Bu Setu, konsumen memang harus melewati jalan yang masuk gang, tetapi rumah makan ini selalu ramai dan banyak yang mencarinya. Konsumen juga merasa senang dengan suasana desa yang kental sehingga ingin kembali menikmati makanan di rumah makan Bu Setu. Rumah makan Bu Setu tidak membuka cabang di manapun karena dibutuhkan lahan yang sangat luas. Sedangkan berdasarkan pendapatnya Hurriyati (2010:57) saat memilih lokasinya dibutuhkan pertimbangan cermat diantaranya akses, visibilitas, luas tempat parkir dan aman, lalu lintas, persaingan, ekspansi, peraturan pemerintah serta lingkungan.

\section{Landasan Teori dan Pengembangan Hipotesis}

Penawaran produk ke konsumen didasarkan atas kebutuhan serta keinginan. Menurut Kotler dan Keller (dalam Allysa dkk. 2018) mengemukakan bahwa kualitas produk, yakni keahlian sebuah produk bertujuan melaksanakan tugasnya, terdiri dari daya tahan, ketepatan, keandalan, kemudahan mengoperasikan, dan perbaikan maupun atribut bernilai lain. Perusahaan harus memperhatikan kualitas produk yang dimiliki agar produk mampu memberikan kepuasan dan mampu bersaing dengan perusahaan lain. 
Pada penelitian Walukow (2014) menyatakan ada pengaruh kualitas produk pada keputusan pemembelian. Maka kualitas produk sesuai kebutuhan konsumen dapat berpengaruh dalam pengambilan keputusan bertransaksi. Pada penelitian ini menggunakan indikator kualitas produk yang mengacu pada teori Margaretha Fiani dan Edwin Japarianto (2012:1) terdiri dari rasa, tekstur, warna, penampilan dan aroma.

Beberapa indikator pengukuran variabel kualitas produk, salah satunya adalah rasa. Ayam panggang $\mathrm{Bu}$ Setu mempunyai rasa pedas dan gurih yang sesuai dengan pesanan konsumen yang diolah dengan ayam kampung. Saat dimakan, olahan daging ayam panggang terasa lezat, enak, dan gurih karena bumbu yang menempel bisa meresap sampai ke dalam daging. Warna daging ayam panggang yang sudah matang berwarna coklat kekuningan. Warna ayam panggang yang disajikan kepada konsumen berwarna orange kemerahan untuk rasa pedas. Ayam panggang mempunyai tekstur daging yang kering. Ketika dimakan ayam panggang terasa empuk serta mempunyai aroma rempah-rempah dan kayu bakar yang khas. Penampilan ayam panggang ketika masih baru dimasak terlihat segar karena baru dipanggang. Apalagi saat disajikan kepada konsumen yang dilengkapi sayur segar, sambal, serta menu tambahan yaitu urapan, pelas, dan botok tempe. Pengukuran indikator ini berasal dari penelitian terdahulu dan hasil pengamatan yang dilakukan secara langsung ke lapangan maka terdapat dugaan sementara untuk temuan penelitian ini.

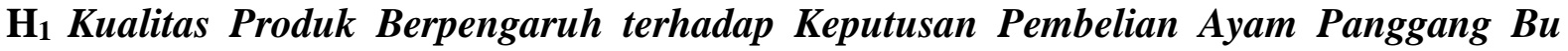 Setu di Gandu Magetan}

Konsumen dapat mengetahui produk yang dibeli dari promosi yang dilakukan pelaku usaha, baik promosi yang masih tradisional maupun promosi yang sudah modern. Mengacu pada banyaknya jumlah pengguna internet di Indonesia sangat berpengaruh terhadap penyebaran informasi melalui electronic word of mouth. Menurut Kietzmann dan Canhoto (dalam Santosa, 2019:146) mengemukakan bahwa Electronic word of mouth adalah pengalaman netral, positif, ataupun negatif untuk calon konsumen perihal sebuah layanan, produk, merek maupun perusahaan yang dipakai serta menyebarkan melalui media internet.

Pada penelitian Patria dkk (2017) menyatakan bahwa ada pengaruh dari electronic word of mouth pada keputusan membeli. Semua informasi dapat diakses dengan mudah karena mempunyai daya jangkau yang cepat dan luas serta dapat di akses di mana saja. Oleh karena itu, penggunaan indikator electronic word of mouth berdasar teori Goyette et al (dalam Santosa, 2019:146) meliputi intensity, valance of opinion, dan content.

Beberapa indikator pengukuran variabel electronic word of mouth yaitu intensity. Intensity berkaitan dengan banyaknya komentar yang ditulis konsumen yang pernah membeli Ayam Panggang $\mathrm{Bu}$ Setu dalam media sosial. Valance of opinion berkaitan dengan banyaknya komentar konsumen terkait rumah makan, kualitas produk, maupun lokasi dari Ayam Panggang Bu Setu serta saran untuk makan di rumah makan Bu Setu pada media sosial. Content berkaitan dengan informasi variasi produk pada media sosial. Pengukuran indikator ini berasal dari penelitian terdahulu dan hasil pengamatan yang dilakukan secara langsung ke lapangan maka terdapat dugaan sementara.

\section{$\mathrm{H}_{2}$ Electronic Word of Mouth Berpengaruh terhadap Keputusan Pembelian Ayam Panggang Bu Setu di Gandu Magetan}

Faktor terpenting melakukan pengembangan bisnis yaitu letak lokasi usaha. Lokasi usaha yang dekat dengan layanan umum, cara pencapaiannya, serta waktu tempuhnya yang 
dibutuhkan untuk sampai ke tempat tujuan. Hurriyati (2010:55) mengemukakan lokasi merupakan tempat pelayanan jasa dipakai untuk pemasokan jasa pada pelanggan akan dituju.

Pada penelitian Hotimah dkk (2018) mengungkapkan bahwa lokasi berpengaruh pada keputusan membeli. Pengambilan keputusan dilakukan konsumen jikalau lokasi yang dituju gampang terjangkau dan mempunyai letak strategis. Indikator lokasi yang digunakan dalam penelitian ini berdasarkan teori Hurriyati (2010:57) yang diukur dengan indikator akses, visibilitas, dan lingkungan.

Beberapa indikator pengukuran variabel lokasi yaitu akses. Lokasi Ayam Panggang Bu Setu mudah dijangkau dengan menggunakan transportasi umum atau kendaraan pribadi. Visibilitas berkaitan dengan lokasinya bisa diketahui dengan jelas dari tepi. Lokasi Ayam Panggang Bu Setu mempunyai alamat serta papan nama jelas yang mudah ditemukan oleh konsumen maupun dapat ditemukan konsumen dengan aplikasi google maps. Lingkungan berkaitan dengan lingkungan sekitar usaha yang dapat membantu jasa yang ditawarkan. Lokasi rumah makan Bu Setu dekat dengan tempat tinggal, tempat kerja maupun fasilitas umum sehingga memudahkan konsumen untuk datang. Pengukuran indikator ini berasal dari penelitian terdahulu dan hasil pengamatan yang dilakukan secara langsung ke lapangan maka terdapat dugaan sementara untuk temuan penelitian ini.

\section{$\mathrm{H}_{3}$ Lokasi Berpengaruh terhadap Keputusan Pembelian Ayam Panggang Bu Setu di Gandu Magetan}

\section{Metode Penelitian}

Penelitian menggunakan jenis penelitian survey dengan pendekatan kuantitatif. Tujuannya untuk pembuktian adanya pengaruh variabel bebas kualitas produk $\left(\mathrm{X}_{1}\right)$, electronic word of mouth $\left(\mathrm{X}_{2}\right)$, lokasi $\left(\mathrm{X}_{3}\right)$, dengan variabel terikat keputusan pembelian $(\mathrm{Y})$. Dengan demikian, rancangan penelitian yang digunakan adalah sebagai berikut :
Kualitas Produk $\left(\mathrm{X}_{1}\right)$ :
1. Rasa $\left(\mathrm{X}_{1.1}\right)$
2. Warna $\left(\mathrm{X}_{1.2}\right)$
3. Tekstur $\left(\mathrm{X}_{1.3}\right)$
4. Aroma $\left(\mathrm{X}_{1.4}\right)$
5. Penampilan $\left(\mathrm{X}_{1.5}\right)$

E-WOM $\left(\mathrm{X}_{2}\right)$ :

1. Intensity $\left(\mathrm{X}_{2.1}\right)$

2. Valance of opinion $\left(\mathrm{X}_{2.2}\right)$

3. Content $\left(\mathrm{X}_{2.3}\right)$

Lokasi $\left(\mathrm{X}_{3}\right)$ :

1. Akses $\left(\mathrm{X}_{3.1}\right)$

2. Visibilitas $\left(X_{3.2}\right)$

3. Lingkungan $\left(X_{3.3}\right)$
$\mathrm{H} 1$

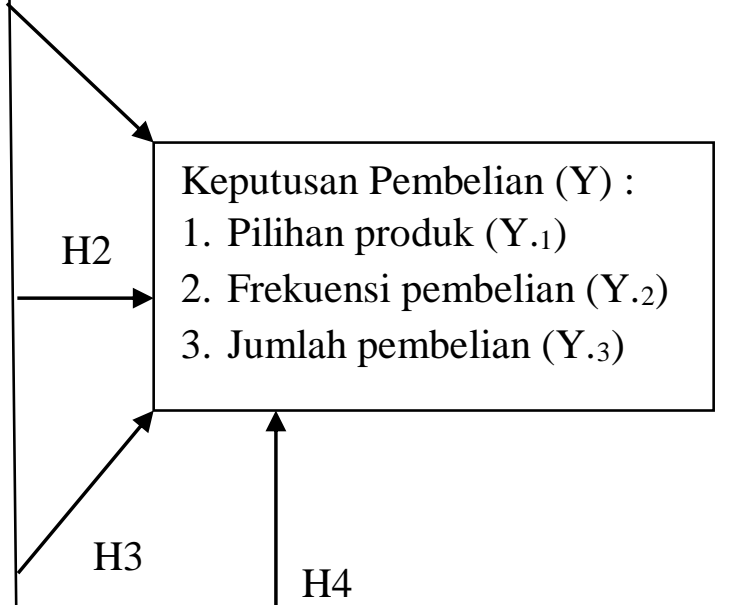

Gambar 1 Rancangan Penelitian 
Adapun definisi operasional dari setiap variabel beserta indikatornya dari penelitian ini dapat dijelaskan sebagai berikut :

\section{a.Kualitas Produk}

Kualitas produk merupakan keseluruhan atas karakteristik yang dimiliki dari suatu produk untuk memenuhi kebutuhan dan keinginan konsumen. Pengukuran kualitas produk yang digunakan dalam penelitian ini berdasarkan pendapat West, Wood dan Harger (2006:39), Gaman dan Sherrington (1996:132) serta Jones (2000:109-110) dalam Fiani dan Edwin (2012:1-2) :

1) Rasa

Titik perasa dari lidah adalah kemampuan mendeteksi dasar yaitu manis, asam, asin, dan pahit. Apabila empat rasa ini digabungkan sehingga menjadi satu rasa yang unik dan menarik untuk dinikmati. Pengukuran indikator rasa menggunakan pernyataan sebagai berikut :

a) Ayam Panggang Bu Setu diolah dengan ayam kampung.

b) Ayam Panggang Bu Setu mempunyai rasa pedas dan gurih.

c) Bumbu Ayam Panggang Bu Setu meresap sampai ke dalam daging.

2) Warna

Warna dari bahan-bahan makanan harus dikombinasikan sedemikan rupa agar mempunyai warna yang serasi. Pengukuran indikator warna menggunakan pernyataan sebagai berikut :

a) Warna daging Ayam Panggang $\mathrm{Bu}$ Setu yang sudah matang berwarna coklat kekuningan.

b) Warna Ayam Panggang Bu Setu berwarna orange kemerahan untuk rasa pedas.

3) Tekstur

Ada banyak tekstur makanan antara lain halus atau tidak, cair atau padat, keras atau lembut, kering atau lembab. Pengukuran indikator tekstur menggunakan pernyataan sebagai berikut :

a) Ayam Panggang Bu Setu mempunyai tekstur daging yang kering.

4) Aroma

b) Ayam Panggang Bu Setu terasa lunak atau empuk.

Aroma merupakan reaksi dari makanan yang akan mempengaruhi konsumen sebelum menikmati makanannya, konsumen dapat mencium makanan tersebut. Pengukuran indikator aroma menggunakan pernyataan sebagai berikut :

a) Olahan daging Ayam Panggang Bu Setu mempunyai aroma bumbu rempahrempah.

b) Olahan daging Ayam Panggang Bu Setu mempunyai aroma kayu bakar yang khas, baik saat sedang dimasak maupun saat disajikan.

5) Penampilan

Makanan harus baik dilihat saat berada dipiring karena hal tersebut adalah salah satu faktor yang penting. Kesegaran dan kebersihan dari makanan yang disajikan adalah contoh penting yang akan mempengruhi penampilan makanan baik atau tidak untuk dinikmati. Pengukuran indikator penampilan menggunakan pernyataan sebagai berikut:

a) Penampilan Ayam Panggang Bu Setu ketika masih baru dimasak terlihat segar karena baru dipanggang.

b) Saat disajikan Ayam Panggang Bu Setu dilengkapi sayur segar, sambal, serta menu tambahan yaitu urapan, pelas, dan bothok tempe. 


\section{b. Electronic Word of Mouth (E-WOM)}

Electronic Word of Mouth (E-WOM) merupakan pernyataan yang dibuat oleh konsumen yang tidak saling mengenal dan bertemu sebelumnya mengenai produk atau jasa melalui media internet. Pengukuran Electronic Word of Mouth (E-WOM) yang digunakan dalam penelitian ini berdasarkan Goyette et al (2010:11) dalam Santosa (2019:146) :

1) Intensity (intensitas), berhubungan dengan banyaknya pendapat yang ditulis oleh konsumen dari sebuah situs jejaring sosial. Pengukuran indikator intensity menggunakan pernyataan sebagai berikut :

a) Banyak komentar dari konsumen yang pernah membeli Ayam Panggang Bu Setu dalam jejaring sosial.

2) Valance of Opinion (pendapat konsumen), berkaitan dengan pendapat konsumen, baik positif maupun negatif terkait produk, jasa, dan brand. Valance of opinion memiliki sifat positif dan negatif. Pengukuran indikator valance of opinion menggunakan pernyataan sebagai berikut:

a) Banyak komentar konsumen terkait rumah makan Bu Setu pada jejaring sosial.

b) Banyak komentar konsumen terkait kualitas ayam panggang kampung $\mathrm{Bu}$ Setu pada jejaring sosial.

c) Banyak komentar konsumen terkait lokasi rumah makan Bu Setu pada jejaring sosial.

d) Banyak saran dari konsumen untuk makan di rumah makan Bu Setu pada jejaring sosial.

3) Content (konten), merupakan isi informasi dalam situs jejaring sosial yang berkaitan dengan produk maupun jasa. Pengukuran indikator content menggunakan pernyataan sebagai berikut:

a) Komentar konsumen yang menceritakan ayam panggang kampung Bu Setu pada jejaring sosial.

b) Komentar konsumen tentang kualitas rasa, tampilan produk, dan variasi menu tambahan Ayam Panggang Bu Setu pada jejaring sosial.

\section{c.Lokasi $\left(\mathbf{X}_{3}\right)$}

Lokasi merupakan tempat dimana suatu usaha dapat dilakukan untuk memberikan pelayanan kepada konsumen. Pengukuran lokasi atau tempat yang digunakan dalam penelitian ini berdasarkan pendapat dari Hurriyati (2010:57) :

1) Akses merupakan lokasi usaha mudah dijangkau oleh transportasi umum maupun kendaraan pribadi. Pengukuran indikator akses menggunakan pernyataan sebagai berikut :

a) Lokasi Ayam Panggang Bu Setu mudah dijangkau.

b) Rute menuju rumah makan Bu Setu menantang karena jalan berkelok-kelok melewati kampung.

2) Visibilitas berkaitan dengan tempat atau lokasi yang dapat dilihat dengan jelas dari tepi jalan. Pengukuran indikator visibilitas menggunakan pernyataan sebagai berikut :

a) Lokasi Ayam Panggang Bu Setu mempunyai alamat dan papan nama yang jelas sehingga mudah ditemukan oleh konsumen.

b) Lokasi Ayam Panggang $\mathrm{Bu}$ Setu dapat ditemukan konsumen dengan menggunakan aplikasi google maps.

3) Lingkungan merupakan daerah sekitar usaha yang mendukung jasa yang ditawarkan. Pengukuran indikator lingkungan menggunakan pernyataan sebagai berikut :

a) Lokasi rumah makan Bu Setu dekat dengan fasilitas umum. 
b) Lokasi rumah makan Bu Setu berada di daerah pedesaan yang padat penduduk dengan suasana lingkungan yang asri dan sejuk.

\section{d. Keputusan Pembelian (Y)}

Keputusan pembelian merupakan suatu proses tindakan yang dilakukan oleh konsumen yang mengarah kepada pembelian akhir untuk membeli suatu produk yang paling disukai, baik barang atau pun jasa. Pengukuran keputusan pembelian yang digunakan dalam penelitian ini berdasarkan Kotler dan Keller (2005:202) dalam Marina dan Saino (2015:5) :

1) Pilihan produk

Konsumen dapat mengambil keputusan pembelian terhadap produk atau membelanjakan uangnya untuk tujuan lain. Dalam hal ini perusahaan harus memusatkan perhatiannya kepada konsumen yang mempunyai niat untuk melakukan pembelian terhadap produk serta alternatif yang akan dipertimbangkan. Pengukuran indikator pilihan produk menggunakan pernyataan sebagai berikut :

a) Konsumen dapat memilih dua varian dari cita rasa di Ayam Panggang Bu Setu yaitu rasa pedas dan rasa gurih pada ayam kampung.

b) Konsumen dapat memilih ayam panggang kampung yang sudah dipesan dimakan di tempat atau dibungkus.

2) Frekuensi pembelian

Konsumen memutuskan seberapa sering membeli produk dan memutuskan pilihan waktu yang tepat karena setiap konsumen mempunyai waktu yang berbeda-beda dalam membeli produk. Pengukuran indikator frekuensi pembelian menggunakan pernyataan sebagai berikut :

a) Konsumen sering melakukan pembelian ulang lebih dari satu kali dalam satu bulan pada Ayam Panggang Bu Setu.

b) Konsumen dapat berkunjung dan membeli Ayam Panggang Bu Setu pada pagi, siang, sore, dan malam buka jam 07.00-21.30 WIB.

3) Jumlah pembelian

Konsumen mengambil keputusan terkait berapa banyak produk yang akan dibeli serta terjadi kemungkinan bahwa konsumen akan membeli produk lebih dari satu. Pengukuran indikator jumlah pembelian menggunakan pernyataan sebagai berikut :

a) Konsumen membeli lebih dari satu porsi atau sesuai dengan permintaan pada Ayam Panggang Bu Setu.

Tempat penelitian dilaksanakan di Rumah Makan Ayam Panggang Bu Setu Gandu Magetan.Populasi meliputi konsumen yang sudah melaksanakan pembelian minkimal 2 kali pada Ayam Panggang Bu Setu. Teknik sampling memakai nonprobability sampling dengan accidental sampling. Jumlah sampel sebanyak 153 responden. Karakteristik responden pada penelitian ialah konsumen minimal dua kali sudah melakukan pembelian, berusia paling rndah 17 tahun, dan satu kelompok diwakili oleh satu orang atau orang yang mengambil keputusan membeli. Instrumen pengumpulan data menggunakan observasi dan angket.

\section{Pembahasan}

Bisnis kuliner di Kabupaten Magetan sudah mengalami perkembangan yang sangat pesat yang berdampak terhadap bertambah banyaknya pilihan bagi konsumen. Namun, keberadaan Ayam Panggang Bu Setu tetap sebagai rumah makan yang paling diminati oleh masyarakat Magetan dan sekitarnya. 


\section{Karakteristik Responden}

Penelitian ini menyebarkan angket penelitian kepada 153 responden yang telah membeli di rumah makan Ayam Panggang Bu Setu. Hasil dari penyebaran angket diketahui bahwa karakteristik responden pada jenis kelamin didominasi oleh perempuan sejumlah 82 responden. Berdasarkan usianya didominasi usia 25-35 tahun jumlahnya 61. Pada orang yang mengambil keputusan pembelian diketahui bahwa semua responden adalah orang yang mengambil keputusan pembelian yaitu 153. Sedangkan pada karakteristik frekuensi pembelian terdominasi lebih dari 3 kali yakni sejumlah 91orang.

\section{Hasil Analisis Data}

Uji instrumen, yaitu uji validitas dan reliabilitas angket dengan jumlah 30 responden di luar jumlah sampel. Dari hasil uji instrument diperoleh hasil sebagai berikut:

\section{Uji Validitas}

Hasil uji validitas diketahui nilai sig hitung seluruhnya memiliki nilai lebih kecil dari 0,3 sehingga semua item pernyataan valid dan layak digunakan.

2.Uji Reliabilitas

Di hasil uji reliabilitas dapat dilihat nilai Cronbach's Alpha seluruh item lebih besar dari 0,60. Maka dapat disimpulkan bahwa seluruh item pernyataan layak dan bisa dipakai untuk pengumpulan data.

Sebelum dilakukan analisis data terlebih dahulu dilakukan uji data dengan menggunakan uji asumsi klasik. Hasil uji asumsi klasik sebagai berikut :

\section{Uji Multikolonieritas}

Hasil uji multikolonieritas pada penelitian ini yakni memperoleh nilai Tolerance untuk variabel kualitas produk $\left(\mathrm{X}_{1}\right)$ besarnya 0,724 , untuk electronic word of mouth $\left(\mathrm{X}_{2}\right)$ sebesar 0,772 , serta untuk lokasi $\left(\mathrm{X}_{3}\right)$ sejumlah 0,828. Apabila dilihat melalui nilai VIF variabel kualitas produk $\left(\mathrm{X}_{1}\right)$ sebesar 1,382 , pada electronic word of mouth $\left(\mathrm{X}_{2}\right)$ sebesar 1,296 , serta lokasi $\left(X_{3}\right)$ sebesar 1,207. Dengan demikian variabel kualitas produk $\left(X_{1}\right)$, EWOM $\left(\mathrm{X}_{2}\right)$, serta lokasi $\left(\mathrm{X}_{3}\right)$ dapat dikatakan tidak terjadi korelasi diantara variabel bebasnya.

2.Uji Glejser

Hasil uji glejser pada penelitian ini diukur dengan cara meregresi nilai absolut residual pada variabel bebasnya di mana $5 \%$ probabilitas pada signifikansinya berada di atas kepercayaan. Hasil nilai signifikan pada variabel kualitas produk sebesar 0,293. Nilai electronic word of mouth sebesar 0,938. Sedangkan nilai signifikan untuk variabel lokasi sejumlah 0,670. Maka menunjukkan bahwa tidak ada gejala heteroskedastisitas karena nilai setiap variabel bebas mempunyai nilai signifikan $>0,05$ sehingga uji glejser pada penelitian ini sudah memenuhi.

3.Uji Normalitas

Hasil uji normalitas dalam penelitian ini memakai uji statistik non parametrik Kolmogorov - Smirnov yang memiliki nilai Asymp. Sig. (2-taileid) adalah 0,286. Mengacu dari hasil tersebut data sudah berdistribusi normal karena nilai signifikansi yang terdapat pada Kolmogorov - Smirnov lebih besar 0,05, sehingga uji normalitas pada penelitian ini sudah memenuhi. 


\section{Uji Linieritas}

Uji linieritas riset ini menghasilkan nilai DW sebesar 1,912. Pada nilai du (batas atas) diperoleh dari pendistribusian tabel DW berdasarkan total variabel bebasnya $3(k=3)$ serta keseluruhan responden $(n=153)$ dengan signifikansi 5\%. Oleh karena itu, nilai du $(1,7758)<$ DW $(1,912)<4$-du $(2,2242)$ sehingga tidak terjadi gejala autokorelasi.

Teknik analisis menggunakan regresi linier berganda, yaitu penggunaan analisis untuk mengidentifikasi pengaruh antara variabel bebasnya yakni kualitas produk $\left(\mathrm{X}_{1}\right)$, electronic word of mouth $\left(\mathrm{X}_{2}\right)$, serta lokasi $\left(\mathrm{X}_{3}\right)$ terhadap variabel terikatnya yaitu keputusan pembelian (Y). Sedangkan pada analisis koefisien determinan (Adjuster R Square) digunakan untuk mengukur seberapa kuat model untuk menerangkan variabel bebas pada model tersebut. Maka uji T (parsial) bertujuan mengidentifikasikan seberapa kuat pengaruh variabel bebas kualitas produk $\left(\mathrm{X}_{1}\right)$, electronic word of mouth $\left(\mathrm{X}_{2}\right)$, dan lokasi $\left(\mathrm{X}_{3}\right)$ memiliki pengaruh signifikan pada keputusan pembelian (Y) atau tidak.

Dari data yang telah dikumpulkan, setelah dilakukan pengolahan data maka hasil regresi linier berganda sebagai berikut :

Tabel 1 Hasil Regresi Linier Berganda

\section{Coefficients $^{\mathrm{a}}$}

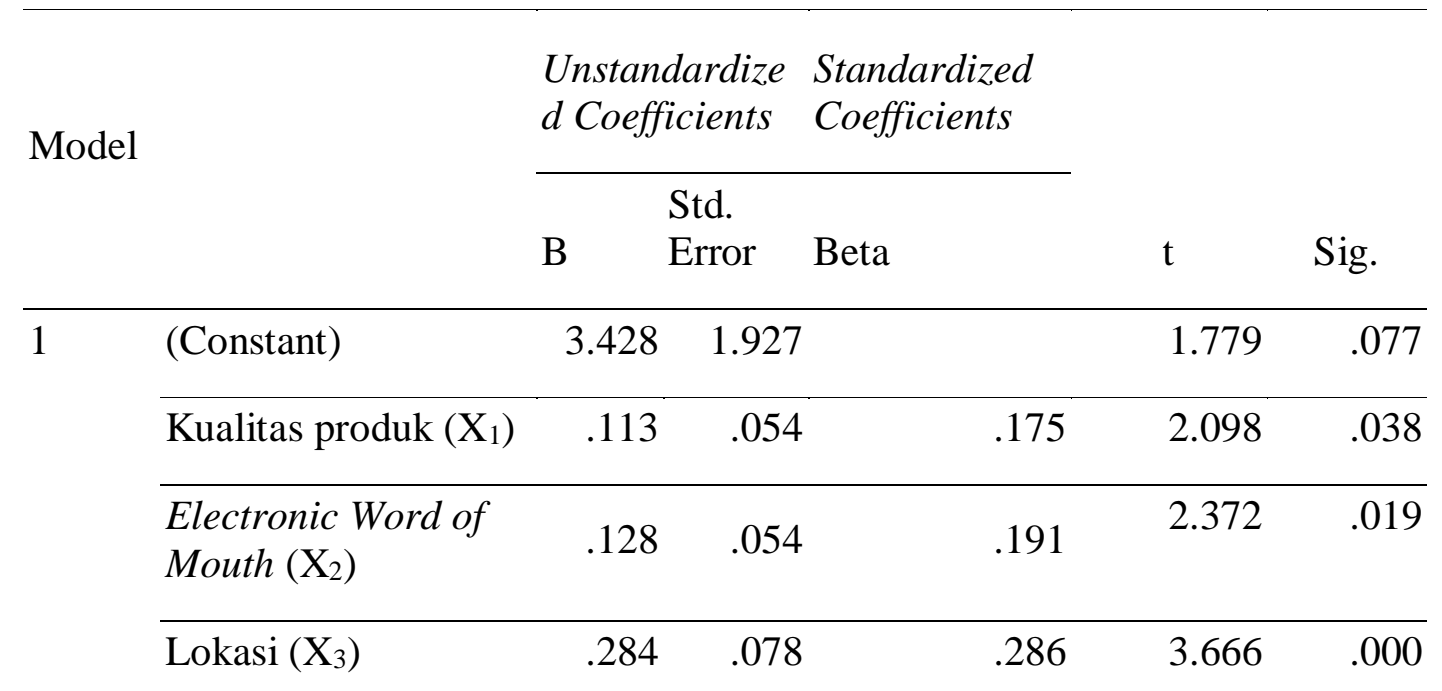

Sumber : Print out dari SPSS for Windows 16.0 berikut.

Dari tabel 1 di atas, maka dapat dirumuskan model dari hasil pengolahan data sebagai

$$
\mathrm{Y}=3,428+0,113_{\mathrm{X} 1}+0,128_{\mathrm{X} 2}+0,284_{\mathrm{X} 3}+\mathrm{e}
$$

Mengacu dipersamaan regresi linier berganda tersebut bisa dijabarkan sebagai berikut:

1.Nilai konstantanya sebesar 3,428, berarti apabila variabel bebas, yakni kualitas produk $\left(\mathrm{X}_{1}\right)$, electronic word of mouth $\left(\mathrm{X}_{2}\right)$, serta lokasi $\left(\mathrm{X}_{3}\right)$ tetap atau tidak terjadi perubahan, tetap terjadi keputusan pembelian (Y). Perihal tersebut menunjukkan nilai konstanta yang positif. Hal ini terjadi karena ada variable lain yang mempengaruhi yang tidaka diteliti. 
2.Nilai koefisien regresi pada kualitas produk sebesar 0,113 . Hal tersebut menunjukkan terjadinya peningkatan keputusan pembeliannya sebanyak 0,113 . Semakin tinggi kualitas produk, maka akan meningkatkan terjadinya keputusan pembelian.

3.Nilai koefisien regresi untuk electronic word of mouth sebesar 0,128. Hal tersebut menunjukkan keputusan pembelian mengalami peningkatan sebanyak 0,128. Semakin meningkat electronic word of mouth, maka akan meningkatkan keputusan pembelian.

4.Nilai koefisien regresi pada lokasi sebesar 0,284. Hal tersebut menunjukkan peningkatan keputusan pembelian sebanyak 0,284. Semakin menarik lokasi usaha, akan meningkatkan keputusan pembelian.

\section{Pengaruh Kualitas Produk terhadap Keputusan Pembelian Ayam Panggang Bu Setu di Gandu Magetan}

Hasil penelitian (pada tabel 2 di bawah) menjelaskan kualitas produk $\left(\mathrm{X}_{1}\right)$ pada

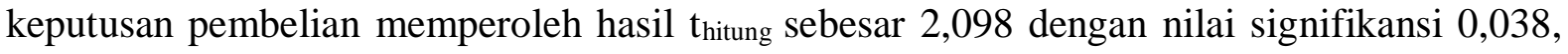
di mana mempunyai nilai siqnifikansi $<0,05$ sehingga menerima Hipotesis $0\left(\mathrm{H}_{0)}\right.$ artinya secara parsial kualitas produk mempunyai pengaruh signifikan terhadap keputusan pembelian.

Berdasar hasil dari uji parsial (t) yang sudah dilaksanakan, maka dapat disimpulkan bahwa kualitas produk $\left(\mathrm{X}_{1}\right)$ adalah linier atau berbanding lurus. Artinya apabila kualitas produk ditingkatkan, maka akan berdampak positip terhadap peningkatan keputusan membeli. Sedangkan, jika kualitas produk diturunkan, maka keputusan pembelian terjadi penurunan. Hal tersebut diperkuat adanya temuan yang dilaksanakan Ulansari dan Edwar (2017) yang menyatakan kualitas produk membuktikan secara signifikan terhadap keputusan pembelian. Kesimpulan tersebut selaras dengan temuan penelitian ini berdasarkan uji t yang menyatakan terdapat hubungan berbanding lurus di antara kualitas produk dengan keputusan pembelian pada Ayam Panggang Bu Setu di Gandu Magetan.

Dari hasil jawaban responden melalui angket pernyataan yang menyatakan saat disajikan ayam panggang Bu Setu dilengkapi sayur segar, sambal, serta menu tambahan yaitu urapan, pelas, dan botok tempe mempunyai nilai mean tertinggi di mana sebagian besar responden menilai sangat setuju bahwa saat disajikan ayam panggang Bu Setu dilengkapi sayur segar, sambal, serta menu tambahan yaitu urapan, pelas, dan botok tempe.

Ayam panggang $\mathrm{Bu}$ Setu diolah dengan menggunakan rempah-rempah asli racikan sendiri dari keluarga Bu Setu dengan tetap memperhatikan kualitas dari semua bahan yang dibutuhkan. Penampilan dari sajian menu makanan ayam panggang kampung mampu menarik perhatian konsumen karena dilengkapi dengan beberapa sayuran segar serta diolah dengan cara tradisional sehingga olahan daging dari produk tersebut mempunyai aroma kayu bakar yang khas.

Hasil penelitian ini selaras dengan penelitian Aminudin (2015) mengemukakan kualitas produk berpengaruh pada keputusan pembelian konsumen di KFC Mega Mas Manado. Kemudian, penelitian berikut sejalan pada argumen Kotler dan Armstrong (2012:283) dalam Saidani dan Arifin (2012:4-5) menyatakan kualitas produk ialah daya dari produk untuk menirukan kegunaan diantaranya semua reliabilitas, durabilitas, kemudahan pengoperasian ketepatan serta reparasi produk maupun atribut produk lain. Jadi, dapat disimpulkan bahwa kualitas produk berpengaruh pada keputusan pembelian Ayam Panggang Bu Setu di Gandu Magetan. 


\section{Pengaruh Electronic Word of Mouth Keputusan Pembelian Ayam Panggang Bu Setu di Gandu Magetan}

Hasil dalam penelitian (pada tabel 3 dibawah) menunjukkan bahwa electronic word of mouth $\left(\mathrm{X}_{2}\right)$ pada keputusan pembelian memperoleh hasil $t_{\text {hitung }}$ sebesar 2,372 dengan nilai signifikansi 0,019 . Nilai siqnifikansi $<0,05$ sehingga menerima Hipotesis $0\left(\mathrm{H}_{0)}\right.$, artinya secara parsial electronic word of mouth mempunyai pengaruh signifikan pada keputusan pembelian.

Berdasarkan hasil uji parsial (t) yang telah dilaksanakan dapat diambil kesimpulan bahwa electronic word of mouth $\left(\mathrm{X}_{2}\right)$ adalah linier atau berbanding lurus. Apabila variabel tersebut ditingkatkan, keputusan pembelian akan meningkat pula. Sedangkan, apabila electronic word of mouth diturunkan, maka terjadi penurunan pada keputusan pembelian. Hal ini diperkuat oleh penelitian Wahyu dkk (2016) mengemukakan bahwa dengan signifikan electronic word of mouth pada keputusan pembelian. Sehingga kesimpulan tersebut selaras dengan penelitian ini yang mengacu terhadap uji t yakni adanya hubungan berbanding lurus diantara electronic word of mouth dengan keputusan pembelian Ayam Panggang Bu Setu di Gandu Magetan.

Dari hasil jawaban responden melalui angket pernyataan yang menyatakan komentar konsumen tentang kualitas rasa, tampilan produk, dan variasi menu tambahan Ayam Panggang Bu Setu pada jaringan sosial mempunyai nilai mean tertinggi di mana mayoritas responden sangat setuju dengan adanya komentar konsumen terkait kualitas rasa, tampilan produk, dan variasi menu tambahan dari produk Bu Setu pada jaringan sosial.

Konsumen yang pernah membeli Ayam Panggang Bu Setu banyak yang memberikan komentar pada sosial media terkait dengan kualitas ayam panggang $\mathrm{Bu}$ Setu, tampilan produk, variasi menu tambahan ayam panggang Bu Setu, serta lokasi rumah makan Bu Setu. Selain itu, pada sosial media juga banyak saran yang diberikan konsumen untuk makan di rumah makan Bu Setu.

Penelitian ini selaras dengan penelitian Firdaus dan Taufik Abdullah (2017) yang menyampaikan yakni electronic word of mouth mempunyai pengaruh dikeputusan pembelian. Selanjutnya, penelitian ini juga sesuai dengan penelitian Akbar dan Sunarti (2018) mengungkapkan electronic word of mouth mempunyai pengaruh pada keputusan pembelian. Kietzmann dan Canhoto (2013) dalam Santosa (2019:146) berpendapat electronic word of mouth ialah pernyataan yang berasal pada pengalaman positif, netral, maupun negatif yang diperoleh calon konsumen tentang layanan, produk, perusahaan ataupun merek yang dibuat serta disebarkan melalui media internet. Oleh karena itu, dapat disimpulkan bahwa electronic word of mouth berpengaruh terhadap keputusan pembelian Ayam Panggang $\mathrm{Bu}$ Setu di Gandu Magetan.

\section{Pengaruh Lokasi terhadap Keputusan Pembelian Ayam Panggang Bu Setu di Gandu Magetan}

Hasil dalam penelitian (pada tabel 4 di bawah) menunjukkan variabel lokasi $\left(\mathrm{X}_{3}\right)$ pada keputusan pembelian memperoleh hasil $t_{\text {hitung }}$ sebesar 3,666 dengan nilai signifikansi 0,000. Nilai siqnifikansi $<0,05$ disimpulkan menerima Hipotesis $0\left(\mathrm{H}_{0}\right)$ artinya lokasi mempunyai pengaruh secara parsial dan signifikan terhadap keputusan pembelian.

Hasil uji parsial (t) yang telah dilaksanakan menyimpulkan bahwa variabel lokasi $\left(\mathrm{X}_{3}\right)$ adalah linier atau berbanding lurus. Jadi, dapat dijelaskan apabila lokasi usaha ditingkatkan 
semakin baik maka keputusan pembelian akan mengalami peningkatan juga. Sebaliknya, apabila lokasi semakin tidak menarik, maka keputusan pembelian juga akan menurun. Hal tersebut diperkuat dengan temuan penelitian dari Lili dan Afriani (2017) mengemukakan bahwa lokasi secara signifikan mempunyai pengaruh pada keputusan pembelian. Kesimpulan tersebut mengacu pada uji t, di mana dinyatakan terdapat hubungan berbanding lurus diantara lokasi dengan keputusan pembelian pada Ayam Panggang Bu Setu di Gandu Magetan.

Dari hasil jawaban responden melalui angket pernyataan yang menyatakan lokasi Ayam Panggang Bu Setu dapat ditemukan konsumen dengan menggunakan aplikasi google maps mempunyai nilai mean tertinggi di mana sebagian besar responden menilai sangat setuju bahwa lokasi Ayam Panggang $\mathrm{Bu}$ Setu dapat ditemukan konsumen dengan menggunakan aplikasi google maps.

Lokasi Ayam Panggang Bu Setu mempunyai akses yang mudah dijangkau dengan memakai kendaraan pribadi ataupun transportasi umum. Lokasi rumah makan $\mathrm{Bu}$ Setu mempunyai alamat dan papan nama yang jelas dan dapat ditemukan dengan menggunakan aplikasi google maps. Selain itu, lokasi Ayam Panggang Bu Setu berada di daerah pedesaan dekat dengan rumah penduduk dengan suasana lingkungan yang asri dan sejuk.

Hasil penelitian ini selaras dengan penelitian Hakim (2016) yang menyatakan variabel lokasi berpengaruh positif dan signifikan pada keputusan pembelian. Hurriyati, (2010:55) mengemukakan bahwa lokasi merupakan penggunaan tempat pelayanan jasa untuk pemasokan jasa pada pelanggan yang akan dituju. Oleh karena itu, keputusan terkait letak pemakaian lokasi harus dekat dengan perkotaan, waktu tempuh lokasi menuju tempat tujuannya serta cara pencapaian. Jadi, dapat disimpulkan bahwa lokasi berpengaruh pada keputusan pembelian Ayam Panggang Bu Setu di Gandu Magetan.

\section{Pengaruh Kualitas Produk, Electronic Word of Mouth, dan Lokasi terhadap Keputusan Pembelian Ayam Panggang Bu Setu di Gandu Magetan}

Berdasarkan pada hasil penelitian memperlihatkan bahwa variabel lokasi berpengaruh paling dominan pada keputusan pembelian Ayam Panggang Bu Setu di Gandu Magetan. Hal tersebut dikarenakan variabel kualitas produk, electronic word of mouth, serta lokasi mempunyai pengaruh secara simultan pada keputusan pembelian. Karena lokasi mempunyai pengaruh yang paling dominan, maka lokasi mempunyai fungsi paling dominan saat mempengaruhi keputusan pembelian konsumen. Adanya lokasi yang gampang terjangkau, alamat dan papan nama yang jelas maupun lingkungan yang berada di daerah pedesaan dan dekat rumah penduduk mampu mempengaruhi konsumen dalam mengambil keputusan pembelian Ayam Panggang Bu Setu di Gandu Magetan.

Selaras dengan penelitian Himawan dkk (2016) yang mengemukakan bahwa variabel kualitas produk dan lokasi memiliki pengaruh pada keputusan pembelian. Hasil penelitian Purwaningdyah (2019) juga menyatakan bahwa electronic word of mouth berpengaruh positif serta signifikan pada keputusan pembelian. Jadi, dapat disimpulkan adanya pengaruh antara kualitas produk, electronic word of mouth, dan lokasi terhadap keputusan pembelian Ayam Panggang Bu Setu di Gandu Magetan. 
INOBIS: Jurnal Inovasi Bisnis dan Manajemen Indonesia

Volume 02, Nomor 04, September 2019

Yulia Anggraini Puspitaningtyas, Saino

Tabel 2. Nilai Koefisien Determinasi $\left(\mathrm{R}^{2}\right)$

\begin{tabular}{|c|c|c|c|c|}
\hline Model & $\mathrm{R}$ & $R$ Square & Adjusted R Square & $\begin{array}{l}\text { Std. Error of } \\
\text { the Estimate }\end{array}$ \\
\hline 1 & 0,501 & 0,251 & 0,236 & 1,441 \\
\hline
\end{tabular}

Sumber : Print out dari SPSS for Windows 16.0

Berdasar tabel 5 nilai koefisien determinasinya (Adjusted $R$ Square) diperoleh sebesar 0,236. Sesuai nilai tersebut dapat dinyatakan bahwa model tersebut dapat menjelaskan variabilitas dari variabel yang diteliti yaitu kualitas produk, electronic word of mouth, serta lokasi sebesar 23,6\%, sedangkan sisanya sejumlah 76,4\% dijelaskan oleh variabel lainnya yang tidak termasuk pada model.

Tabel 3. Hasil Uji F (Simultan)

\begin{tabular}{lrrrrr}
\hline Model & Sum of Squares & df & Mean Squares & F & \multicolumn{2}{c}{ Sig } \\
\hline Regression & 103.877 & 3 & 34.626 & 16,687 & 0,000 \\
\hline Residual & 309.182 & 149 & 2.075 & & \\
\hline Total & 413.059 & 152 & & & \\
\hline
\end{tabular}

Sumber : Print out dari SPSS for Windows 16.0

Pada tabel 6 hasil uji F dapat diketahui yakni nilai F hitung sebanyak 16,687 memiliki nilai signifikansi sebesar 0,000. Karena nilai signifikansinya lebih kecil dari pada 0,05 Hipotesis $\mathrm{H}_{4}$ diterima, yang berarti kualitas produk, electronic word of mouth, serta lokasi secara simultan berpengaruh pada keputusan pembelian.

\section{Kesimpulan}

Berdasarkan pada hasil analisis penelitian yang sudah dilaksanakan, dapat disimpulkan bahwa kualitas produk secara parsial mempunyai pengaruh positif dan signifikan terhadap keputusan pembelian, electronic word of mouth secara parsial mempunyai pengaruh positif dan signifikan terhadap keputusan pembelian, lokasi secara parsial mempunyai pengaruh positif dan signifikan terhadap keputusan pembelian, dan variabel kualitas produk $\left(\mathrm{X}_{1}\right)$, electronic word of mouth $\left(\mathrm{X}_{2}\right)$, serta lokasi $\left(\mathrm{X}_{3}\right)$ secara simultan berpengaruh positif dan signifikan terhadap keputusan pembelian (Y) Ayam Panggang Bu Setu di Gandu Magetan.

\section{Daftar Pustaka}

Akbar, Muhammad Juliatrin Chairul dan Sunarti. (2018).Pengaruh Electronic Word of Mouth Terhadap Keputusan Pembelian (Studi Pada Konsumen Restoran Sushi Tei Kelapa Gading). Jurnal Administrasi Bisnis. Vol 60. No 3.

Allysa, Nindia dkk. (2018). Pengaruh Kualitas Produk Terhadap Keputusan Pembelian Pada Ozon Parfum Fragrance. Prosiding Manajemen. Vol. 4. No 2. ISSN : 2460-6545.

Aminudin, Lucky. (2015).Pengaruh Kualitas Produk, Promosi, dan Store Atmosfir terhadap Keputusan Pembelian Konsumen pada KFC Mega Mas Manado. Jurnal Berkala Ilmiah Efisiensi. Vol. 15 (5) : hal 703-715. 
Fiani, Margaretha dan Edwin Japarianto. (2012).Analisis Pengaruh Food Quality dan Brand Image terhadap Keputusan Pembelian Roti Kecik Toko Roti Ganep's di Kota Solo. Jurnal Manajemen Pemasaran. Vol. 1 (1). hal : 1-6.

Firdaus, Taufansyah dan Taufik Abdullah. (2017). E-WOM Pengaruhnya Terhadap Keputusan Pembelian Tamu Restoran di Bandung Utara. Tourism and Hospitality Essentials Journal. Vol. 7. No. 1.

Himawan, Baron dkk. (2016). Pengaruh Kualitas Produk, Kualitas Pelayanan, dan Lokasi Terhadap Keputusan Pembelian Konsumen di Warung Mie Ayam Bakso Ajeng Karanganyar. Jurnal Ekonomi dan Kewirausahaan. Vol. 16 No. 3 : hal 346-353.

Hotimah dkk. (2018).Pengaruh Kualitas Pelayanan, Harga, dan Lokasi Terhadap Keputusan Pembelian di Rumah makan Sederhana Sumbersuko Lumajang. Jurnal Riset Manajemen. Vol.1. No.1.

Hurriyati, Ratih. (2010). Bauran Pemasaran dan Loyalitas Konsumen. Bandung : Alfabeta

Patria, Dwina Tresna dkk. (2017). "Pengaruh Electronic Word Of Mouth terhadap Keputusan Pembelian pada Warung Instamie Bandung”. Prosiding Manajemen. Vol. 3 (1). ISSN: 2460-6545.

Purwaningdyah, Sri Wiludjeng Sunu. (2019). Pengaruh Electronic Word of Mouth dan Food Quality Terhadap Keputusan Pembelian. Jurnal Manajemen Maranatha. Vol. 19. No. 1. ISSN : 1411-9293.

Saidani, Basrah dan Samsul Arifin. (2012).Pengaruh Kualitas Produk dan Kualitas Layanan Terhadap Kepuasan Konsumen dan Minat Beli Pada Ranch Market. Jurnal Riset Manajemen Sains Indonesia. Vol.3. No. 1. 